\title{
Effect of Environment on Survival of Eggplant, Pepper, and Tomato in a Small-scale Healing Chamber
}

\author{
Fairuz A. Buajaila, Pinki Devi, and Carol A. Miles ${ }^{1}$
}

ADDITIONAL INDEX WORDs. light intensity, relative humidity, temperature, SPAD

SumMARY. Many small-scale vegetable growers in the United States who graft their own vegetable transplants use healing chambers inside a greenhouse to heal their grafted plants. Under these conditions, light and relative humidity $(\mathrm{RH})$ can fluctuate during the healing process, and growers need more research-based information regarding the impact of these factors on the survival of grafted transplants. To address this need, this study investigated the effect of different targeted levels of light $(0 \%, 25 \%$, and $50 \%)$ and $\mathrm{RH}(50 \%$ and $100 \%)$ (six combinations) in a small-scale healing chamber within a greenhouse, where the healing chamber was opened for increasing periods of time for 8 days, at which time plants were fully exposed to greenhouse conditions. The survival and growth of selfgrafted eggplant (Solanum melongena), pepper (Capsicum annuum), and tomato (Solanum lycopersicum) were measured up to 25 days post grafting. Percent light in the closed healing chambers was similar for the $50 \%$ and $100 \%$ RH levels of each light treatment. When the healing chambers were closed, compared with the greenhouse, there was $0.1 \%$ light in the $0 \%$ light treatments, $25 \%$ light on average in the $25 \%$ light treatments, and $43 \%$ light on average in the $50 \%$ light treatments. On days 2 to 5 after grafting, when chambers were opened up to 1 hour, average $\mathrm{RH}$ in the healing chambers was $96 \%$ to $98 \%$ for the $100 \% \mathrm{RH}$ treatments, and was $42 \%$ to $49 \%$ for the $50 \% \mathrm{RH}$ treatments. On days 6 and 7, when chambers were opened for 3 to 8 hours, $\mathrm{RH}$ was $79 \%$ to $82 \%$ for the $100 \% \mathrm{RH}$ treatments, and was $39 \%$ to $46 \%$ for the $50 \% \mathrm{RH}$ treatments. Survival of grafted plants following healing was greatest when the healing chamber treatment was $100 \% \mathrm{RH}$ and $50 \%$ or $25 \%$ light (95\% and $90 \%$ survival, respectively), and plant survival with these two treatments did not significantly decline from 11 to 21 days after grafting, indicating plants were fully healed and acclimated when they were removed from the healing chambers on day 8 . At 22 to 25 days following grafting, plants healed with $100 \%$ $\mathrm{RH}$ and $50 \%$ or $\mathbf{2 5 \%}$ light had greater plant height, number of leaves per plant, and stem diameter than plants healed in the other light and $\mathrm{RH}$ combinations. SPAD reading and nitrate-nitrogen of fresh petiole sap were unaffected by any of the healing treatments tested in this experiment, or by crop type. Tomato and pepper had $14 \%$ greater survival rates on average than eggplant at all measurement dates, while tomato tended to have greater plant growth, followed by eggplant and pepper. Additional research is needed to improve survival of grafted eggplant.

G rafting is a horticultural technique that joins scion (top) and rootstock plants via a graft union to create desirable aboveground and below-ground characteristics in the grafted plant (Davis et al., 2008). Grafting has been used for decades in commercial vegetable production in Asia and Europe to manage

Department of Horticulture, Northwestern Washington Research and Extension Center, Washington State University, Mount Vernon, WA 98273

We gratefully acknowledge technical assistance provided by Patricia Kreider and Edward Scheenstra, statistical analysis assistance by Shuresh Ghimire, and funding support provided by the Libyan Ministry of Higher Education \& Scientific Research, USDANIFA SCRI Grant No. 2011-51181-30963, and State project WN00375-Acc. No. 1008680.

${ }^{1}$ Corresponding author. E-mail: milesc@wsu.edu.

https://doi.org/10.21273/HORTTECH04103-18 plant diseases, increase plant vigor, and improve plant production, but is still not widely used in the United States (Kubota et al., 2008; Lee, 1994; Lee et al., 2010; Peregrine and Binahmad, 1982; Sakata et al., 2007). Adoption of grafted plants among small-scale growers in the United States is limited by a shortage of research-based information regarding the production of grafted plants. While large-scale growers in the United States likely purchase grafted transplants, many small-scale growers are grafting their own (Kubota et al., 2008). Solanaceous crops (Solanaceae) are generally considered easy to graft because the splice grafting method that is most commonly used is simple and quick with a high graft survival rate $(\geq 95 \%$ survival for tomato under controlled healing conditions). While grafting generally takes less than a minute per plant to complete, the healing process takes a week. Healing is the process of construction and establishment of the vascular connection between the scion and the rootstock plants (Davis et al., 2008; FernandezGarcia et al., 2004). In general, an environment that includes high relative humidity ( $85 \%$ to $100 \%$ ), low or no light, and temperature ranging from 75 to $80{ }^{\circ} \mathrm{F}$ is believed to be a requirement for obtaining high grafting success with solanaceous crops (Bausher, 2013; Jang et al., 2011; Lee, 1994).

The scion is incapable of absorbing water from the rootstock for several days following grafting, and a high humidity environment can reduce scion transpiration and prevent plant wilting (Fernandez-Garcia et al., 2004; Turquois and Malone, 1996). The light conditions during the healing process can also affect plant transpiration since reduced light levels minimize stomatal opening and inhibit the photosynthesis process (Oda, 1999; Rivard and Louws, 2011). Overall, grafting survival is improved due to the conservation of water in the plant (Jang et al., 2011). However, photosynthesis is required for cell division, which is needed for vascular regeneration and callus formation (Hunter et al., 2004; Taiz and Zeiger, 2002). Callus proliferation in both the rootstock and the scion are needed for vascular connection at the

\begin{tabular}{llll}
\hline $\begin{array}{l}\text { Units } \\
\begin{array}{l}\text { To convert U.S. to SI, } \\
\text { multiply by }\end{array}\end{array}$ & U.S. unit & SI unit & $\begin{array}{l}\text { To convert SI to U.S., } \\
\text { multiply by }\end{array}$ \\
\hline 29.5735 & $\mathrm{fl} \mathrm{oz}$ & $\mathrm{mL}$ & 0.0338 \\
2.54 & inch(es) & $\mathrm{cm}$ & 0.3937 \\
25.4 & inch(es) & $\mathrm{mm}$ & 0.0394 \\
0.4536 & $\mathrm{lb}$ & $\mathrm{kg}$ & 2.2046 \\
10.7639 & lumen $(\mathrm{s}) / \mathrm{ft}^{2}$ & $\mathrm{~lx}$ & 0.0929 \\
1 & $\mathrm{ppm}$ & $\mathrm{mg} \cdot \mathrm{L}^{-1}$ & 1 \\
$\left({ }^{\circ} \mathrm{F}-32\right) \div 1.8$ & ${ }^{\circ} \mathrm{F}$ & ${ }^{\circ} \mathrm{C}$ & $\left({ }^{\circ} \mathrm{C} \times 1.8\right)+32$
\end{tabular}

Hortlechnology · October 2018 28(5) 
rootstock-scion interface (Ogata et al., 2005), and poor callus formation can lead to low rates of survival of grafted plants (Johkan et al., 2008, 2009; Oda et al., 2005). Carbohydrates are required for callus formation, and are produced in the plant through photosynthesis (Hunter et al., 2004; Milthorpe and Moorby, 1979; Taiz and Zeiger, 2002). When light is limited in the healing chamber, healing of grafted plants is dependent on stored carbohydrates (Daley et al., 2014). For example, the survival of watermelon (Citrullus lanatus) grafted using the splice grafting technique (both rootstock cotyledons were removed) was $89 \%$ when rootstocks received $2 \%$ sucrose solution before grafting and the rootstock stems had $52 \%$ starch accumulation. In comparison, rootstocks that were treated with water had $6 \%$ starch accumulation in the rootstock stems and grafting success was $58 \%$ (Dabirian and Miles, 2017). There are no reports regarding increasing the carbohydrate reserves of solanaceous crops before grafting, though previous research reports that when light is provided during the healing period, callus induction, growth and graft survival are improved (Afshari et al., 2011; Moon and Stomp, 1997; Nobuoka et al., 2005).

While large-scale producers of grafted vegetable transplants use controlled environments to heal newly grafted plants, small-scale growers are using simple healing chamber structures within a greenhouse, where it can be difficult to precisely control environmental factors. There are no standard guidelines for managing small-scale healing chambers, as climate conditions and greenhouse structures vary considerably across regions (O'Connell et al., 2009). An earlier experiment carried out in a greenhouse at Mount Vernon, WA measured grafting success following healing with three different healing chamber structures: a commercial propagator's design that was covered in clear plastic and shadecloth, and was hand misted (used by a large-scale vegetable grafting company in British Columbia, Canada); a research design that was also covered in clear plastic and shadecloth but that used a humidifier (commonly used in the southeastern United States); and a simple structure that was only covered in shadecloth and was hand misted (used by small-scale tomato growers who graft their own transplants) (Johnson and Miles, 2011). The commercial propagator healing chamber structure had the highest temperature and $\mathrm{RH}\left(24.9{ }^{\circ} \mathrm{C}\right.$ and $98 \%$, respectively), while the research structure had a slightly lower temperature and moderately lower $\mathrm{RH}\left(23.4^{\circ} \mathrm{C}\right.$ and $81 \%$, respectively), and the shadecloth structure also had slightly lower temperature but substantially lower $\mathrm{RH}$ $\left(23.3^{\circ} \mathrm{C}\right.$ and $52 \%$, respectively). The authors concluded that high $\mathrm{RH}$ during the 7 - $\mathrm{d}$ healing period was necessary for eggplant and watermelon graft survival $(82 \%$ and $7 \%$ grafting survival overall, respectively), but not necessary for tomato graft survival (98\% grafting survival overall). However, the light levels were not measured in this study.

There is a need to provide more information for small-scale growers who are healing grafted plants using simple healing structures inside a greenhouse, with a range of fluctuating light and $\mathrm{RH}$ levels. Thus, the objective of this study was to investigate the effect of a range of light and $\mathrm{RH}$ levels on the grafting success of tomato, eggplant, and pepper in a small healing chamber within a greenhouse environment.

\section{Materials and methods}

EXPERIMENTAL DESIGN. This study was carried out in a greenhouse at Washington State University (WSU) Northwestern Washington Research and Extension Center (NWREC) in Mount Vernon, WA (lat. $48^{\circ} 26^{\prime} 17.00^{\prime \prime} \mathrm{N}$, long. $\left.122^{\circ} 23^{\prime} 35.04^{\prime \prime} \mathrm{W}\right)$. The experimental design was a split-plot randomized complete block with six healing chamber treatments and three crops, and the study was repeated three times (each repeat was a replicate). The main plot treatment was healing chamber environment, and the subplot treatment was vegetable crop: eggplant, pepper, and tomato. The main plot treatments were six combinations of light $(0 \%, 25 \%$, and $50 \%)$ and $\mathrm{RH}(100 \%$ and $50 \%)$ during the 8 -d healing period. Light was ambient sunlight plus greenhouse light provided by $600-\mathrm{W}$ high-pressure sodium bulbs (GLE6240A E-Ballast; PARsource Lighting Solutions, CA) with a $15 \mathrm{~h}$ photoperiod (6:00 AM to 9:00 PM). The treatments were chosen as they represent the range of light and $\mathrm{RH}$ levels that small-scale growers are using in the United States to heal grafted solanaceous crops, especially grafted tomato, which some growers heal in a shaded part of a greenhouse. The study was repeated three times in 2017: 5 Jan. to 21 Feb., 30 Jan. to 19 Mar., and 1 Mar. to 19 Apr.

Healing Chamber treatments. Six clear plastic boxes [length 24 inches $\times$ width 17 inches $\times$ height 13 inches (Hefty; HMS, Troy, MI)] were placed open side down on a greenhouse bench and used as healing chambers for the grafted plants. Each box was covered based on a preliminary study conducted $27 \mathrm{Feb}$. to 3 Mar. 2016 that determined the necessary coverings at this time of year to attain the targeted light and RH conditions for each treatment in the study. In the preliminary study, light was $0.1 \%$ for the $0 \%$ light treatment, $26 \%$ for the $25 \%$ light treatment (range was $23 \%$ to $28 \%$ ), and $55 \%$ for the $50 \%$ light treatment (range was $48 \%$ to $60 \%$ ). Because it is not possible to precisely control light and RH levels in the greenhouse environment used for this study, and levels varied as the healing chambers were opened and closed during the 8 - $\mathrm{d}$ healing period, the target values are given as treatment levels. To attain $0 \%$ light, all sides and the top of the box were covered with two layers of black landscape fabric (Geotex 200ST; Propex Operating Co., Chattanooga, TN). To attain 25\% light, all sides and the top of the box were covered with one layer of white paper [ 24 inches wide, 40-lb (Kraft Paper Roll; Pacon Corp., Appleton, WI)] and two layers of white rowcover (Agribon +; Polymer Group, Sanluis Potosi, Mexico). To attain $50 \%$ light, the top and the two long sides of the box were covered with white paper. The coverings on the boxes were maintained throughout the healing period. To attain $100 \% \mathrm{RH}$, the inside surfaces and floor (the lid of the box was used as the floor) of the healing chamber were sprayed with water, and the chamber was closed. To attain $50 \%$ $\mathrm{RH}$, the same procedure was followed except there was a $1.5-\mathrm{cm}$ opening at the bottom of one short side of the healing chamber (the opening was created by resting the box on two metal blocks). Water was added to the floor and walls of all the healing 
chambers each day as needed to maintain the $\mathrm{RH}$ treatments, and soil moisture was checked daily to ensure it was adequate.

Plant material and grafting. 'Traviata' eggplant, 'Ace' pepper, and 'Big Beef' tomato (all Johnny's Selected Seeds, Winslow, ME) were selected for this study as all are commonly grown cultivars in northwestern Washington. For each repeat, seeds were sown in the greenhouse into 72 -cell $(59-\mathrm{mL})$ trays that were filled with commercial sphagnumpeat-based media (Sunshine \#l Natural \& Organic; Sun Gro Horticulture, Vancouver, BC, Canada). The day before grafting, plants were randomized in a 72-cell tray with one empty row between each crop type. Each treatment in repeat 1 included 13 tomato, 20 eggplant, and 20 pepper seedlings; repeat 2 included 20 tomato, 15 eggplant, and 10 pepper seedlings; and repeat 3 included 20 seedlings of each crop type. Differences in plant number for each repeat were due to disproportionate seed germination even though a preexperiment germination test was conducted and each plant type was over-seeded accordingly.

The day before grafting, plant watering was reduced such that potting mix in each cell was moist but no water bubble formed at the cut stem. About $22 \mathrm{~d}$ after seeding, when plant stems were 1.5 to $3.0 \mathrm{~mm}$ diameter, the splice grafting method was used to self-graft plants (Johnson et al., 2011). Self-grafting was used to minimize the potential effects of genetic incompatibility and conflicting rootstock and scion angles on graft survival. Grafting occurred from 8:30 AM to 11:30 AM for each repeat, the part of the day when transpiration and water stress were lowest (Rivard and Louws, 2006). The stem of each plant was cut under the cotyledons at an approximate $45^{\circ}$ angle using a razor blade (Wilkinson Sword, High Wycombe, UK), and cut surfaces were placed back together and held in place with a silicon grafting clip ( 1.5 or $2 \mathrm{~mm}$; Harris Seed, Rochester, NY). After grafting, plants for each crop were immediately placed into one of the six healing chamber treatments for the 8-d healing period.

Graft Healing. Healing followed the protocol developed for this region (Johnson et al., 2016), and is summarized here. The day when grafting occurred was referred to as day 1 . Healing chambers were not opened and plants were not disturbed for the remainder of day 1 and all of day 2. To gradually acclimate the plants to the greenhouse environment, the healing chambers were opened (the box was removed from the plants) for $5 \mathrm{~min}$ on day $3,30 \mathrm{~min}$ on day $4,1 \mathrm{~h}$ on day $5,3 \mathrm{~h}$ on day 6 , and 6 to 8 h on day 7 . On day 8 , plants were removed from the chambers at 10:00 $\mathrm{AM}$, and plants were grown on the bench in greenhouse conditions for the remainder of the study. Temperature, light, and $\mathrm{RH}$ in the six healing chambers were measured every $\mathrm{l} h$ with data loggers (HOBO; Onset Computer Corp., Bourne, MA) for the 8-d healing period after grafting. Temperature and $\mathrm{RH}$ were measured in the greenhouse on days 1 through 8 following grafting, and light was measured when plants were fully exposed to greenhouse conditions.

Plant survival and growth. Survival of grafted plants was rated visually $11,14,17$, and $21 \mathrm{~d}$ after grafting based on wilting of the scion. The turgidity of scion leaves and stems was estimated using a scale of 0 to 3 where $0=$ completely turgid leaves and stems, $1=$ up to $50 \%$ of leaves and stems flaccid, $2=$ up to $70 \%$ of leaves and stems flaccid, and $3=$ completely wilted leaves and stems. The number of plants with wilt rating of 0 were recorded as successfully grafted. The number of leaves, plant height (from the soil line to the top of the plant crown), and distance from the soil line to the graft union were recorded on day 22 after grafting. Plant height reflects general plant growth, while the distance from the soil line to the graft union provides a measure of stem elongation, which is important after transplanting to avoid contact between the scion and the soil (to avoid transfer of soil-borne pathogens). Stem diameter was measured $\approx 1 \mathrm{~cm}$ above the graft union using a digital caliper (model 700-126; Mitutoyo, Aurora, IL) 23 d after grafting.

Leaf greenness is a factor of chlorophyll content and plant nitrogen $(\mathrm{N})$ status, and is an indicator of general plant health. Relative leaf greenness was measured with a SPAD meter (Minolta, Tokyo, Japan) on day 23 after grafting on each plant that "survived" according to the described rating system. The measurement was taken on the lateral middle leaf blade (left middle section of the leaf, from the leaf apex) of the oldest true leaf; the leaf was left intact on the plant for the measurement. On day 25 after grafting, nitrate- $\mathrm{N}$ was measured in the fresh petiole sap of the youngest fully mature leaf; leaf samples were collected between 11:00 AM and 2:00 PM (Brust, 2008; Hochmuth, 1994). Fresh petiole sap was extracted from all samples using a mortar and pestle, and four to five drops of the sap from each sample was placed on the sensor of a Cardy nitrate meter (Horiba Scientific, Edison, NJ) and the amount of nitrate (parts per million) was recorded.

Data analysis. All data were subjected to analysis of variance in JMP (version 11.0 for Windows; SAS Institute, Cary, NC). Homogeneity of variances was assessed in all cases using Levene's test, and normality by Shapiro-Wilk test $(\mathrm{W}>0.80)$. Data for SPAD meter readings and nitrate- $\mathrm{N}$ measurements were transformed for statistical analysis to meet the assumptions of normality and homogeneity of variances by using square root transformation for SPAD meter readings and natural log transformation for nitrate- $\mathrm{N}$ measurements, but non-transformed data are presented and means are reported in their raw units. Treatment means were compared using LSMeans Student's test at $\alpha=0.05$.

\section{Results}

Healing Chamber environMENTS. Inside the healing chambers, the mean daily temperature was similar for the six treatments throughout the three study repeats (Fig. 1). The overall mean temperature for all treatments was $80^{\circ} \mathrm{F}$, the overall minimum temperature was $78^{\circ} \mathrm{F}$, and the overall maximum temperature was $83^{\circ} \mathrm{F}$. The overall average temperature in the greenhouse was $79^{\circ} \mathrm{F}$ for the three repeats, and the range was 72 to $86^{\circ} \mathrm{F}$.

For each of the three light treatments, the maximum light intensity inside the healing chambers while they were closed was similar for the $50 \%$ and $100 \% \mathrm{RH}$ levels: 1 lumen $/ \mathrm{ft}^{2}$ for the $0 \%$ light treatments, 260 and 277 lumens $/ \mathrm{ft}^{2}$ for $25 \%$ light treatments, and 383 and 390 lumens $/ \mathrm{ft}^{2}$ 

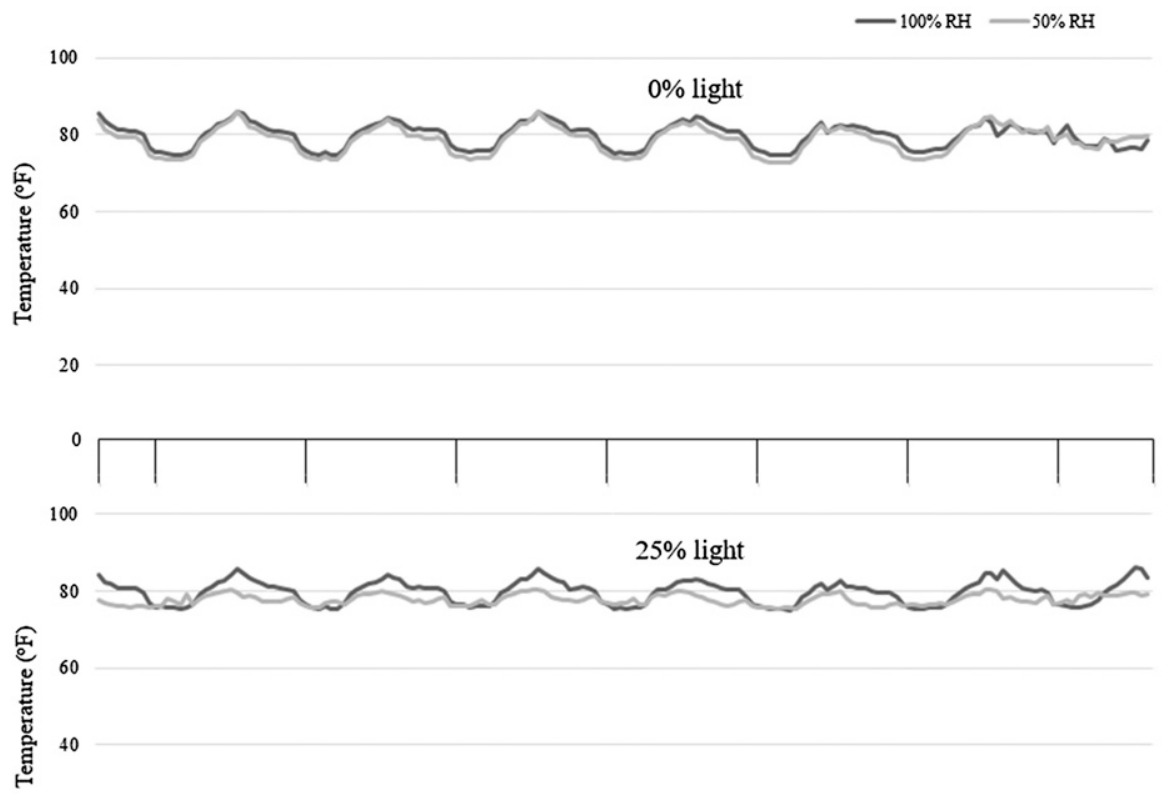

20
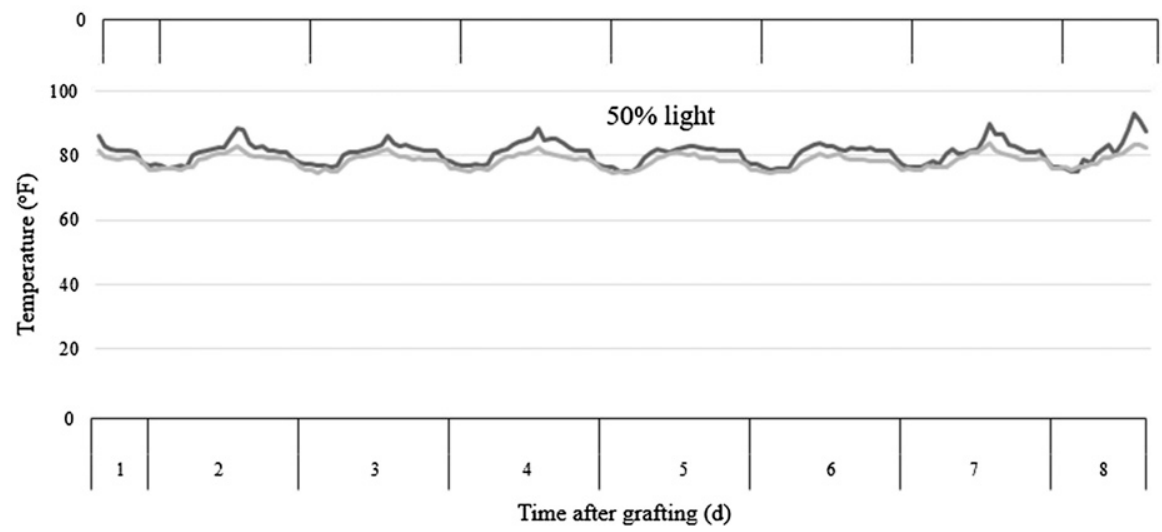

Fig. 1. Daily average temperature for the three light treatments $(0 \%, 25 \%$, and $50 \%)$ combined for the two relative humidity $(\mathrm{RH})$ treatments $(50 \%$ and $100 \%)$ in the healing chambers during the 8-d healing period after grafting for the three repeats in 2017 (27 Jan. to 3 Feb., 22 Feb. to 1 Mar., and 24 Mar. to 31 Mar.) in a greenhouse at Washington State University Northwestern Washington Research and Extension Center at Mount Vernon, WA. Data were measured every $1 \mathrm{~h}$ with data loggers (HOBO; Onset Computer Corp., Bourne, $\mathrm{MA}) ;\left({ }^{\circ} \mathrm{F}-32\right) \div 1.8={ }^{\circ} \mathrm{C}$.

for $50 \%$ light treatments, respectively. Further, the light intensity pattern each day was similar for the three repeats, although as expected, light intensity increased throughout the study as the daylength increased. For the $0 \%$ light treatments, essentially no light $(0.1 \%)$ was recorded in the healing chamber for the first $4 \mathrm{~d}$ as the chambers were opened for 30 min or less each day and light was only recorded each hour (Fig. 2). Thereafter, light was present in $0 \%$ light treatments only when the healing chambers were opened $(1 \mathrm{~h}$ on day $5,3 \mathrm{~h}$ on day 6 , and 6 to $8 \mathrm{~h}$ on day 7 ). For the $25 \%$ and $50 \%$ light intensity inside the greenhouse reached a maximum of 1560 lumens $/ \mathrm{ft}^{2}$ for repeat 1 (5 to 12 Jan.), 2143 lumens $/ \mathrm{ft}^{2}$ for repeat $2(30 \mathrm{Jan}$. to 7 Feb.), and 2999 lumens $/ \mathrm{ft}^{2}$ for repeat 3 ( 1 to $8 \mathrm{Mar}$.). The percent light in the closed healing chambers varied by day and repeat, and ranged from $17 \%$ to $36 \%$ in the $25 \%$ light treatments, and was $25 \%$ on average. In the $50 \%$ light treatments, the percent light in the closed healing chambers ranged from $29 \%$ to $54 \%$ and was $43 \%$ on average.

The mean daily $\mathrm{RH}$ in the healing chamber treatments of $100 \% \mathrm{RH}$ with $0 \%, 25 \%$, or $50 \%$ light was $96 \%$, $98 \%$, and $97 \%$, respectively, for days 2 through 5 after grafting, when chambers were opened for $1 \mathrm{~h}$ or less each day (Fig. 3). For days 6 and 7 after grafting, when chambers were opened for $3 \mathrm{~h}$ and $6 \mathrm{~h}$ to $8 \mathrm{~h}$, respectively, the mean daily RH was $80 \%, 82 \%$, and $79 \%$ for the three light treatments, respectively. For the healing chamber treatments of $50 \% \mathrm{RH}$ with $0 \%, 25 \%$, or $50 \%$ light, the mean daily $\mathrm{RH}$ for days 2 to 5 after grafting was $42 \%$, $48 \%$, and $49 \%$, respectively. For days 6 to 8 after grafting, the mean daily $\mathrm{RH}$ was $39 \%, 46 \%$, and $42 \%$, respectively, for the three light treatments. The mean $\mathrm{RH}$ in the greenhouse was $29 \%$, $32 \%$, and $32 \%$ for the first, second, and third repeats, respectively.

GRAFTED PLANT SURVIVAL. Survival (percent) of grafted plants following healing was impacted by the main effects of $\mathrm{RH}$ and light levels on all measurement dates except $11 \mathrm{~d}$ after grafting (Table 1). Plant survival also differed by crop (Table 1): Tomato and pepper had $14 \%$ greater survival on average than eggplant at all measurement dates (Table 2). There was a significant interaction between $\mathrm{RH}$ and light on all measurement dates, but no other interactions were significant (Table 1 ). Survival of grafted plants following healing was greatest when the healing chamber environment was $50 \%$ light and $100 \% \mathrm{RH}(95 \%$ survival), followed by $25 \%$ light and $100 \% \mathrm{RH}$ (90\% survival), and was lowest with $50 \%$ light and $50 \% \mathrm{RH}$ (32\% survival). Plant survival following graft healing with other light and $\mathrm{RH}$ combinations ranged from $56 \%$ to $83 \%$.

Plant growth. Plant height from the soil line to the top of the plant differed significantly based on 

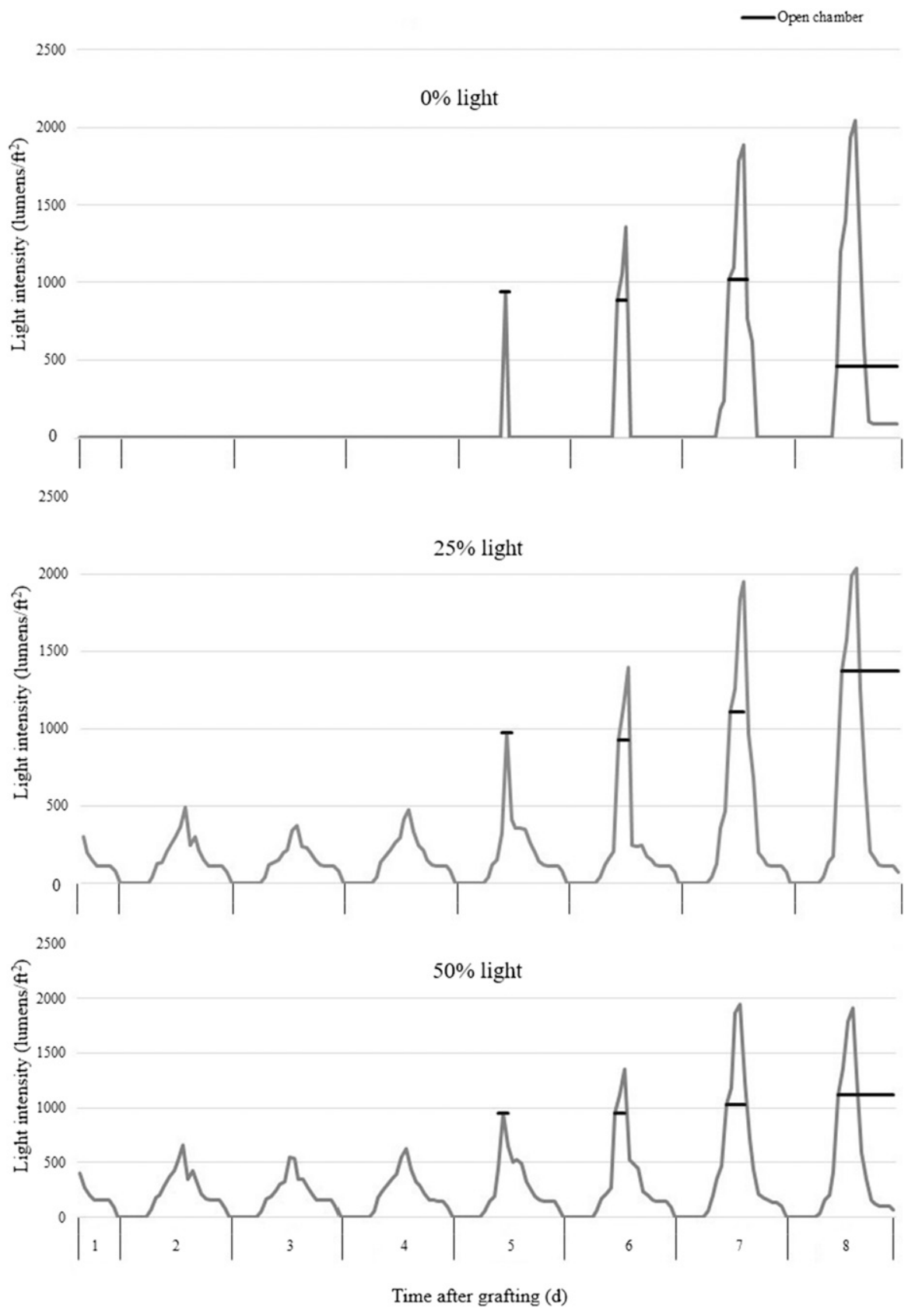

Fig. 2. Light intensity in the healing chamber during the 8-d period after grafting in 2017, with data averaged for three repeats (27 Jan. to $3 \mathrm{Feb}$., $22 \mathrm{Feb}$. to $1 \mathrm{Mar}$., and 24 Mar. to 31 Mar.) of each of the three light treatments, $0 \%, 25 \%$, and $50 \%$, and combined for relative humidity treatment $(50 \%$ and $100 \%)$ within a greenhouse at Washington State University Northwestern Washington Research and Extension Center at Mount Vernon, WA. Data were measured every $1 \mathrm{~h}$ with data loggers (HOBO; Onset Computer Corp., Bourne, MA); 1 lumen $/ \mathrm{ft}^{2}=$ $10.7639 \mathrm{~lx}$.

RH, light, and crop type, and their interactions (Table 3 ). $\mathrm{RH}$ did not affect any other growth parameters measured in this study, whereas light and crop type affected graft height, number of leaves per plant and stem diameter. Plant growth parameters were greatest for grafted plants that were healed with $50 \%$ light and $100 \%$
$\mathrm{RH}$, and were lowest for plants healed with $50 \%$ light and $50 \% \mathrm{RH}$ (Table 4 ). Overall, tomato had the greatest plant height (both from the soil to the top of plant and to the grafting union), number of leaves per plant and stem diameter, followed by eggplant; however, pepper had a greater number of leaves per plant than eggplant.
SPAD readings of healed plants differed based on light treatment ( $\mathrm{Ta}$ ble 3), and was significantly higher for plants healed with $0 \%$ light $(30.0)$ than with $25 \%$ or $50 \%$ light $(29.2$ and 28.7, respectively). There were no other effects on plant SPAD reading by any of the main factors or their interactions. Nitrate-N of healed plants was unaffected by any of the main factors or their interactions $(\mathrm{Ta}-$ ble 3). Overall, plant SPAD reading and nitrate- $\mathrm{N}$ measurement of fresh petiole sap were unaffected by the healing chamber environments tested in this experiment, or by crop type (Table 4).

\section{Discussion and conclusions}

It is inherently difficult to precisely control light and RH levels inside healing chambers that are within a greenhouse structure, commonly used by small-scale growers to heal grafted plants. Furthermore, when the healing protocol includes opening the healing chamber and exposing grafted plants to greenhouse conditions for a period of time each day, it is not possible to use one set of environmental conditions to describe the healing environment. For example, when the healing chambers in this study were opened for an hour or more and then closed, it took several hours for the RH level in the chambers to reach close to the target values. For ease of contrasting results for the treatments in this study, and to provide guidance for growers regarding environmental factors for the healing chambers, the target values of light and $\mathrm{RH}$ were used to compare treatment results.

In this study, grafted plant survival was greatest when plants were healed with $50 \%$ or $25 \%$ light and $100 \% \mathrm{RH}$ for the $8-\mathrm{d}$ healing period. Furthermore, survival of plants healed with these two treatments did not decline from 11 to $21 \mathrm{~d}$ after grafting, indicating plants were fully acclimated when they were removed from the healing chambers on day 8 . In contrast, $50 \%$ and $25 \%$ light combined with $50 \% \mathrm{RH}$ resulted in low survival of grafted plants due to water stress (severe wilting) that likely occurred as a result of photosynthesis and transpiration. These results indicate that it is more important to control RH than light level during the healing process. Light during graft 

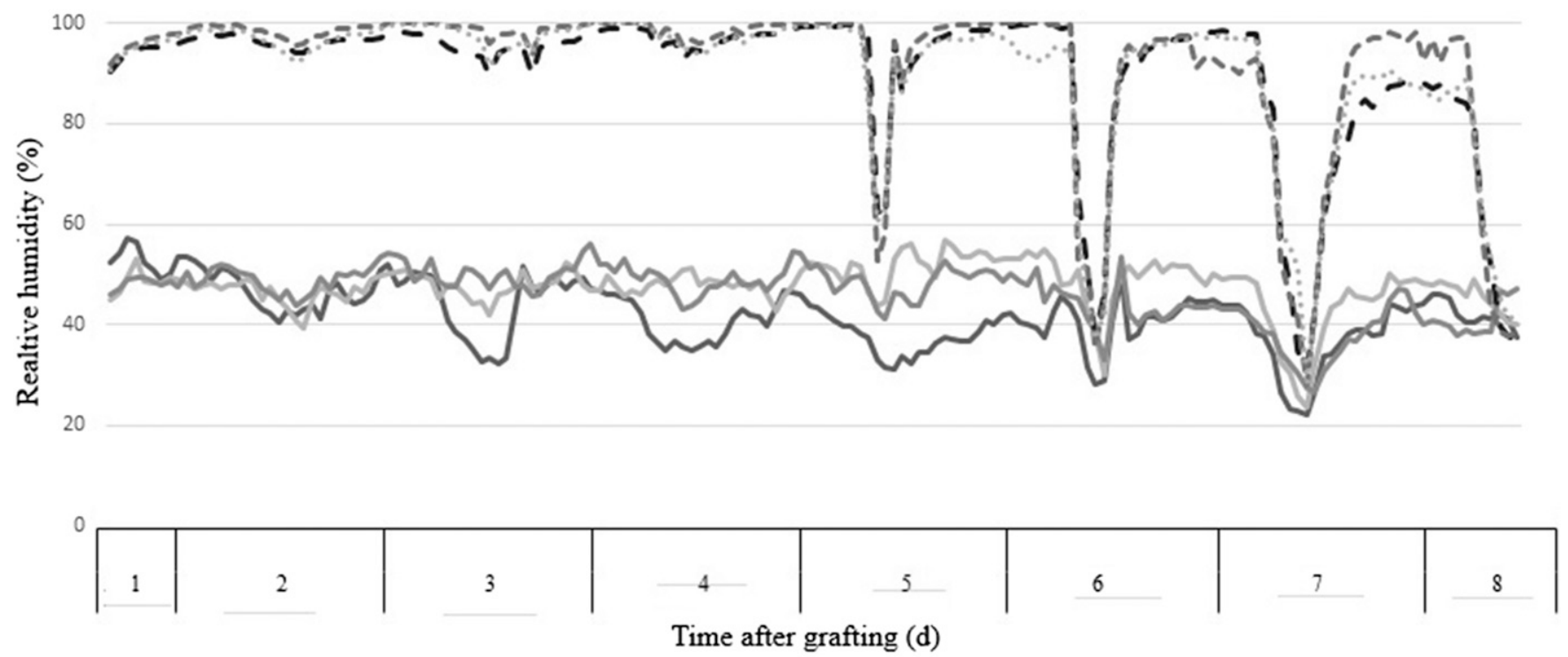

$-0 \%$ Light for $50 \% \mathrm{RH}-25 \%$ Light for $50 \% \mathrm{RH}-50 \%$ Light for $50 \% \mathrm{RH}$
$--0 \%$ Light for $100 \% \mathrm{RH}---25 \%$ Light for $100 \% \mathrm{RH} \cdots \cdots 50 \%$ Light for $100 \% \mathrm{RH}$

Fig. 3. Daily average relative humidity $(\mathrm{RH})$ for the $50 \%$ and $100 \% \mathrm{RH}$ treatments in the healing chambers during the 8 -d healing period after grafting for the three repeats in 2017 ( 5 Jan. to 21 Feb., 30 Jan. to 19 Mar., and 1 Mar. to 19 Apr.) in a greenhouse at Washington State University Northwestern Washington Research and Extension Center at Mount Vernon, WA. Data were measured every $1 \mathrm{~h}$ with data loggers (HOBO; Onset Computer Corp., Bourne, MA).

Table 1. Overall probability values for relative humidity (RH), light and crop, and interactions on percent survival of grafted eggplant, pepper, and tomato.

\begin{tabular}{|c|c|c|c|c|}
\hline \multicolumn{5}{|c|}{$P$ values for survival (\%) at each measurement date ${ }^{\mathrm{z}}$} \\
\hline Treatment & $11 \mathrm{~d}$ & $14 \mathrm{~d}$ & $17 \mathrm{~d}$ & $21 \mathrm{~d}$ \\
\hline $\mathrm{RH}$ & 0.09 & 0.04 & 0.02 & 0.01 \\
\hline Light & 0.28 & 0.03 & 0.001 & 0.0009 \\
\hline Crop & 0.0003 & 0.002 & 0.003 & 0.01 \\
\hline $\mathrm{RH} \times$ Light & 0.004 & $<0.0001$ & $<0.0001$ & $<0.0001$ \\
\hline $\mathrm{RH} \times \mathrm{Crop}$ & 0.17 & 0.67 & 0.40 & 0.51 \\
\hline Light $\times$ Crop & 0.67 & 0.27 & 0.75 & 0.94 \\
\hline Light $\times \mathrm{RH} \times$ Crop & 0.71 & 0.82 & 0.61 & 0.57 \\
\hline
\end{tabular}

${ }^{\mathrm{z}}$ All data were subjected to analysis of variance using ANOVA in JMP (version 11.0 for Windows; SAS Institute, Cary, NC).

healing improved grafting success likely due to plant photosynthesis, which could provide carbohydrates for callus formation and growth of new vascular tissue (Hunter et al., 2004). Several authors have reported that, under controlled healing conditions, photosynthesis, growth, and quality of grafted plants were improved by increasing the light level during the healing and acclimation periods (Jang et al., 2011; Nobuoka et al., 2005). Similarly, $\mathrm{Vu}$ et al. (2014) reported that grafted seedling survival improved with a red lightemitting diode (LED) treatment rather than darkness during the healing period, and light also increased plant height but not number of leaves. The results from the current study indicate that for solanaceous crops $0 \%$ light during graft healing is not optimal for healing success. While plant growth of tomato, eggplant, and pepper plants was enhanced when light was present in the healing chamber, plant SPAD readings and nitrate$\mathrm{N}$ measurement of fresh petiole sap were unaffected by the healing chamber environments tested in this experiment, or by crop type. Thus SPAD readings and nitrate- $\mathrm{N}$ of fresh petiole sap do not appear useful for comparing the effects of different healing environments on plant health following grafting. Overall, plants healed with light were larger by the time they would be ready for transplanting ( $25 \mathrm{~d}$ after grafting); however, because plants are vulnerable to water stress in the days following grafting, high RH is needed to prevent severe wilting when light is present in the healing chamber.

Tomato tended to have the greatest plant survival and growth following grafting in this study, similar to findings of Johnson and Miles (2011). These results indicate that of the three solanaceous crops in the current study, tomato tended to be the easiest with which to achieve grafting success. While eggplant tended to have greater plant growth following grafting than pepper, grafting success for eggplant was lower than for pepper. Additional research is needed to improve survival of grafted eggplant, and may include testing environmental factors in the healing chamber as well as investigating seedling size at the time of grafting, and potentially increasing carbohydrate level in rootstock and scion plants before grafting.

The current study demonstrated that an 8 -d healing period with $50 \%$ light and $100 \% \mathrm{RH}$ inside a small healing chamber within a greenhouse was as effective for grafting success of tomato as reported for controlled 
Table 2. Survival of grafted eggplant, pepper, and tomato plants as a function of varying levels of light and relative humidity $(\mathrm{RH})$ in the healing chamber 11,14 , 17 , and $21 \mathrm{~d}$ after grafting.

\begin{tabular}{|c|c|c|c|c|c|}
\hline \multicolumn{2}{|c|}{ Treatment (\%) } & \multicolumn{4}{|c|}{ Survival $(\%)^{\mathrm{z}}$} \\
\hline Light & RH & $11 \mathrm{~d}$ & $14 \mathrm{~d}$ & $17 \mathrm{~d}$ & $21 \mathrm{~d}$ \\
\hline 0 & 100 & $90 a b^{y}$ & $86 \mathrm{ab}$ & $86 a$ & $83 \mathrm{~b}$ \\
\hline 25 & 100 & $91 \mathrm{ab}$ & 89 a & $90 \mathrm{a}$ & $90 \mathrm{ab}$ \\
\hline 50 & 100 & $95 \mathrm{a}$ & $95 \mathrm{a}$ & $95 \mathrm{a}$ & $95 \mathrm{a}$ \\
\hline 0 & 50 & $71 \mathrm{c}$ & $64 \mathrm{~cd}$ & $60 \mathrm{~b}$ & $56 \mathrm{~d}$ \\
\hline 25 & 50 & $75 \mathrm{bc}$ & $73 \mathrm{bc}$ & $72 \mathrm{~b}$ & $70 \mathrm{c}$ \\
\hline 50 & 50 & $61 \mathrm{c}$ & $50 \mathrm{~d}$ & $39 \mathrm{c}$ & $32 \mathrm{e}$ \\
\hline$P$ value & & 0.004 & 0.0005 & $<0.0001$ & $<0.0001$ \\
\hline \multicolumn{6}{|l|}{ Crop } \\
\hline Eggplant & & $74 \mathrm{~b}$ & $70 \mathrm{~b}$ & $68 \mathrm{~b}$ & $64 \mathrm{~b}$ \\
\hline Pepper & & $82 \mathrm{a}$ & $77 \mathrm{a}$ & $74 \mathrm{ab}$ & $71 \mathrm{ab}$ \\
\hline Tomato & & $86 a$ & $82 \mathrm{a}$ & $80 \mathrm{a}$ & $77 \mathrm{a}$ \\
\hline$P$ value & & 0.0002 & 0.0005 & 0.004 & 0.01 \\
\hline
\end{tabular}

${ }^{\mathrm{z}}$ All data were subjected to analysis of variance using ANOVA in JMP (version 11.0 for Windows; SAS Institute, Cary, NC). Survival was rated by visually estimating the turgidity of scion leaves and stems, using a scale of 0 to 3 where $0=$ completely turgid leaves and stems, $1=$ more than $50 \%$ of leaves and stems flaccid, $2=$ more than $70 \%$ of leaves and stems flaccid, and $3=$ completely wilted leaves and stems; only plants rated as 0 were counted as "survived." ${ }^{\mathrm{y}}$ Means followed by a different letter within sampling date are significantly different at $P<0.05$. healing environments. In the 8 -d period the healing chamber was kept closed on days 1 and 2 following grafting, then opened for $5 \mathrm{~min}$ on day $3,30 \mathrm{~min}$ on day $4,1 \mathrm{~h}$ on day 5 , $3 \mathrm{~h}$ on day 6,6 to $8 \mathrm{~h}$ on day 7 , and on day 8 plants were removed from the chamber. Simple healing methods such as those used in this study are needed to increase rates of grafting among growers who graft their own plants and heal them using small-scale chambers within a greenhouse or a similar structure. Further studies that test light, RH, temperature, and healing chamber protocols at different locations would provide a better understanding of the interactions between greenhouse conditions and healing chamber environment, and the critical environmental parameters for successfully healing grafted plants at different locations.

Table 3. Overall probability values for relative humidity $(\mathrm{RH})$, light and crop, and interactions on plant vigor parameters of grafted eggplant, pepper, and tomato.

\begin{tabular}{|c|c|c|c|c|c|c|}
\hline \multirow[b]{2}{*}{ Treatment } & \multicolumn{6}{|c|}{$P$ values for plant vigor parameters ${ }^{\mathrm{z}}$} \\
\hline & Plant ht ${ }^{y}$ & Graft ht $^{\mathrm{x}}$ & Leaves/plant & Stem diam & SPAD reading & Nitrate nitrogen \\
\hline $\mathrm{RH}$ & 0.006 & 0.13 & 0.06 & 0.11 & 0.15 & 0.36 \\
\hline Crop & $<0.0001$ & $<0.0001$ & $<0.0001$ & $<0.0001$ & 0.45 & 0.58 \\
\hline $\mathrm{RH} \times$ Light & $<0.0001$ & $<0.0001$ & $<0.0001$ & $<0.0001$ & 0.78 & 0.64 \\
\hline $\mathrm{RH} \times \mathrm{Crop}$ & $<0.0001$ & 0.07 & 0.16 & $<0.0001$ & 0.35 & 0.31 \\
\hline
\end{tabular}

${ }^{\mathrm{z}}$ All data were subjected to analysis of variance using ANOVA in JMP (version 11.0 for Windows; SAS Institute, Cary, NC).

yPlant height from the soil line to the top of plant.

${ }^{\mathrm{x}}$ Plant height from the soil line to the grafting union.

Table 4. Mean plant growth parameters for grafted eggplant, pepper, and tomato with varying levels of light and relative humidity $(\mathrm{RH})$ in the healing chamber, 22, 23, and $25 \mathrm{~d}$ after grafting.

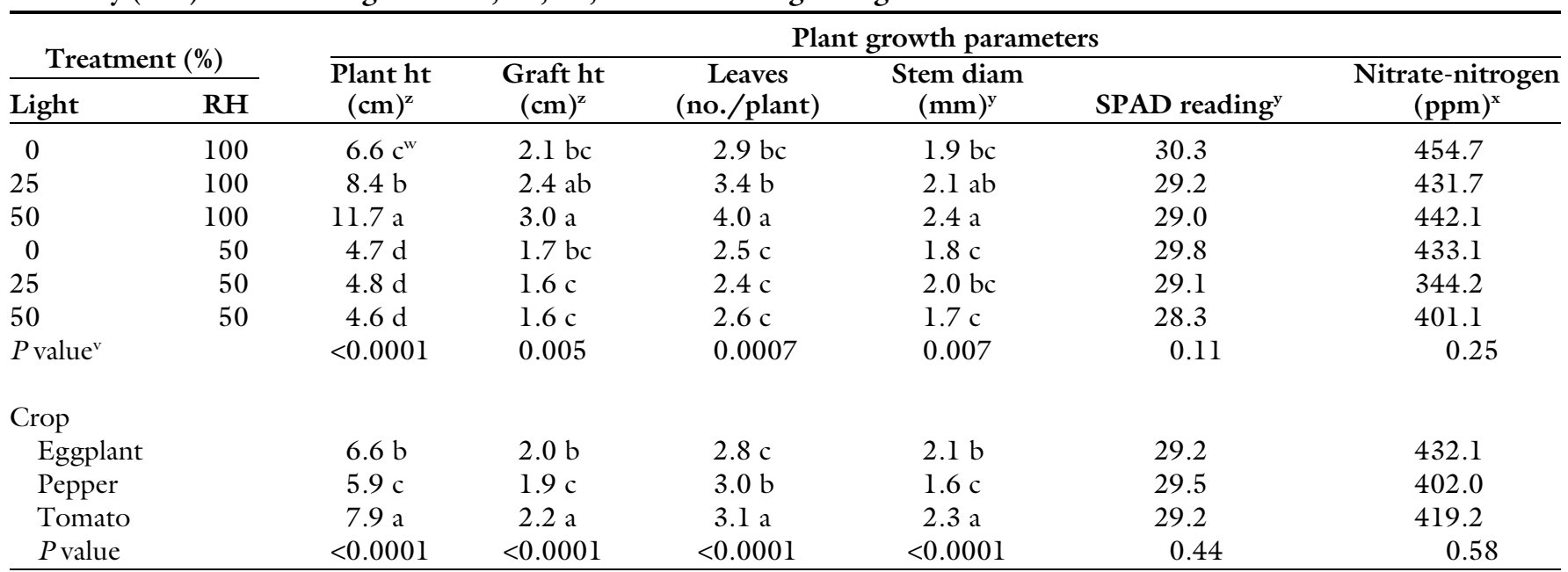

${ }^{\mathrm{z}}$ Plant height, graft union height from the soil, and number of leaves per plant were measured on day 22 after grafting ( 19 Feb., 14 Mar., and 16 Apr. 2017 for first, second, and third repeat, respectively); $1 \mathrm{~cm}=0.3937$ inch.

${ }^{y_{S}}$ Stem diameter and SPAD meter reading were recorded on day 23 after grafting $(20$ Feb., 15 Mar., and 17 Apr. 2017 for first, second, and third repeat, respectively); 1 mm = 0.0394 inch.

${ }^{\mathrm{x}}$ The amount of nitrate- $\mathrm{N}$ was recorded on day 25 after grafting (22 Feb, $17 \mathrm{Mar}$., and $19 \mathrm{Apr} .2017$ for first, second, and third repeat, respectively); $1 \mathrm{ppm}=1 \mathrm{mg} \cdot \mathrm{L}^{-1}$.

"Means followed by a different letter within sampling date are significantly different at $P<0.05$.

vAll data were subjected to analysis of variance using ANOVA in JMP (version 11.0 for Windows; SAS Institute, Cary, NC). 


\section{Literature cited}

Afshari, R.T., R. Angoshtari, and S. Kalantari. 2011. Effect of light and different plant growth regulators on induction of callus growth in rapeseed (Brassica napus L.) genotypes. Plant Omics J. 4:60-67.

Bausher, M.G. 2013. Graft angle and its relationship to tomato plant survival. HortScience 48:34-36.

Brust, G. 2008. Using nitrate-N petiole sap-testing for better nitrogen management in vegetable crops. Univ. Maryland Ext. Publ. Sept. 2008

Dabirian, S. and C. Miles. 2017. Increasing survival of splice-grafted watermelon seedlings using a sucrose application. HortScience 52:579-583.

Daley, S.L., J. Adelberg, and R.L. Hassell. 2014. Improvement of grafted watermelon transplant survival as a result of size and starch increased over time caused by rootstock fatty alcohol treatment: Part 1 . HortTechnology 24:343-349.

Davis, A.R., P. Perkins-Veazie, Y. Sakata, S. Lopez Galarza, J.V. Maroto, S.G. Lee, Y.C. Huh, Z. Sun, A. Miguel, S. King, R. Cohen, and J.M. Lee. 2008. Cucurbit grafting. Crit. Rev. Plant Sci. 27:50-74.

Fernandez-Garcia, N., M. Carvajal, and E. Olmos. 2004. Graft union formation in tomato plants: Peroxidase and catalase involvement. Ann. Bot. 93:53-60.

Hochmuth, G.J. 1994. Plant petiole saptesting for vegetable crops. Univ. Florida. Hort. Sci. Dept. Circ. 1144.

Hunter, J.J., C.G. Volschenk, D.J. le Roux, and L. Adams. 2004. Plant material quality: A compilation of research. ARC InfruitecNietvoorbij, Stellenbosch, South Africa.

Jang, Y.A., E. Goto, Y. Ishigami, B.H. Mun, and C.H. Chun. 2011. Effects of light intensity and relative humidity on photosynthesis, growth and graft-take of grafted cucumber transplants during healing and acclimatization. Hort. Environ. Biotechnol. 52:331-338.

Johkan, M., M. Oda, and G. Mori. 2008. Ascorbic acid promotes graft-take in sweet pepper plants (Capsicum annuum L.). Scientia Hort. 116:343-347.

Johkan, M., K. Mitukuri, S. Yamasaki, G. Mori, and M. Oda. 2009. Causes of defoliation and low survival rate of grafted sweet pepper plants. Scientia Hort. 119:103-107.

Johnson, S. and C. Miles. 2011. Effect of healing chamber design on survival of grafted eggplant, tomato, and watermelon. HortTechnology 21:752-758.

Johnson, S., P. Kreider, and C. Miles. 2011. Vegetable grafting: Eggplants and tomatoes. Washington State Univ. Ext. Publ. FS052E. 30 Nov. 2017. <http://extension.wsu. edu/publications/wp-content/uploads/ sites/54/publications/fs052e.pdf>.

Johnson, S., C. Miles, P. Kreider, and J. Roozen. 2016. Vegetable grafting: The healing chamber. Washington State Univ. Ext. Fact Sheet. FS051E. 15 Nov. 2017. $<$ http://cru.cahe.wsu.edu/CEPublications/ FS051E/FS051E.pdf>.

Kubota, C., M. McClure, N. KokalisBurelle, M.G. Bausher, and E.N. Rosskopf. 2008. Vegetable grafting: History, use, and current technology status in North America. HortScience 43:1664-1669.

Lee, J.M. 1994. Cultivation of grafted vegetables I. Current status, grafting methods, and benefits. HortScience 29: 235-239.

Lee, J.M., C. Kubota, S.J. Tsao, Z. Bie, P.H. Echevarria, L. Morra, and M. Oda. 2010. Current status of vegetable grafting: Diffusion, grafting techniques, automation. Scientia Hort. 127:93-105.

Milthorpe, F.L. and J. Moorby. 1979. An introduction to crop physiology. Cambridge Univ. Press, Cambridge, UK.

Moon, H.K. and A.M. Stomp. 1997. Effects of medium components and light on callus induction, growth, and frond regeneration in Lemna gibba (Duckweed). In Vitro Cell. Dev. Biol. Plant 33:20-25.

Nobuoka, T., T. Nishimoto, and K. Toi. 2005. Wind and light promote graft-take and growth of grafted tomato seedlings. J. Jpn. Soc. Hort. Sci. 74:170-175.
O'Connell, S., S. Hartmann, C.L. Rivard, M.M. Peet, and F.J. Louws. 2009. Grafting tomatoes on disease resistant rootstocks for small scale organic production. 15 Nov. 2017. <http://ofrf.org/ funded/highlights/oconnell_07f30. html>.

Oda, M., M. Maruyama, and G. Mori. 2005. Water transfer at graft union of tomato plants grafted onto Solanum rootstocks. J. Jpn. Soc. Hort. Sci. 74:458463.

Oda, M. 1999. Grafting of vegetables to improve greenhouse production. Food Fert. Technol. Ctr. Ext. Bul. 480

Ogata, T., Y. Kabashima, S. Shiozaki, and S. Horiuchi. 2005. Regeneration of the vascular bundle at the graft interface in auto-and hetero grafts with juvenile nucellar seedlings of satsuma mandarin, yuzu and trifoliate orange. J. Jpn. Soc. Hort. Sci. 74:214-220.

Peregrine, W.T.H. and K. Binahmad. 1982. Grafting - A simple technique for overcoming bacterial wilt in tomato. Trop. Pest Mgt. 28:71-76.

Rivard, C.L. and F.J. Louws. 2011. Tomato grafting for disease resistance and increased productivity. Sustainable Agr. Res. Educ. (SARE) Factsheet GS05-046.

Rivard, C.L. and F.J. Louws. 2006. Grafting for disease resistance in heirloom tomatoes. North Carolina State Univ. Coop. Ext. Serv. 675.

Sakata, Y., T. Ohara, and M. Sugiyama. 2007. The history and present state of the grafting in Japan. Acta Hort. 731:159-170.

Taiz, L. and E. Zeiger. 2002. Plant physiology. 3rd ed. Sinauer Assoc., Sunderland, MA.

Turquois, N. and M. Malone. 1996. Nondestructive assessment of developing hydraulic connections in the graft union of tomato. J. Expt. Bot. 47:701-708.

Vu, N.T., Y.S. Kim, H.M. Kang, and I.S. Kim. 2014. Effect of red LEDs during healing and acclimatization process on the survival rate and quality of grafted tomato seedlings. Protected Hort. Plant Factory 23:43-49. 